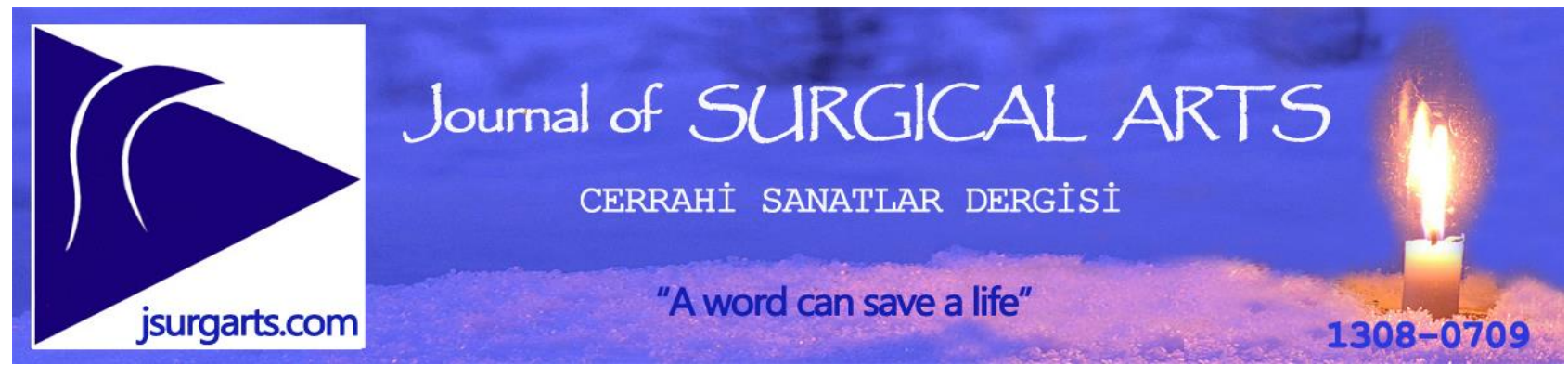

Case report

\title{
Pseudomyxoma peritonei presenting with port site hernia
}

\section{Port yerinde herni bulgularıyla gelen psödomiksoma peritonei olgusu}

\author{
Serkan Karaıslı iD, Atahan Acar iD, Feyyaz Güngör iD, Kemal Atahan \\ Izmir Kâtip Celebi University Ataturk Training and Research Hospital, Department of General Surgery, \\ Izmir-Turkey.
}

Address: Dr. Serkan Karassl1, skaraisli@ hotmail.com

How to cite: Karaislı S, Acar A, Güngör F, Atahan K. Pseudomyxoma peritonei presenting with port site hernia. J Surg Arts 2021;14(2):89-92. DOI: http://dx.doi.org/10.14717/jsurgarts-210208

Received: 30.04.2021 Accepted: 05.07.2021

\section{ABSTRACT}

Pseudomyxoma peritonei (PMP) is a rare disease with an incidence of two per million. Acute appendicitis, ovarian mass, and abdominal distension are the most common presentations. A 72-yearold male patient with a history of laparoscopic cholecystectomy was admitted to the hospital with abdominal pain and increased supraumbilical port site swelling. Radiological examination revealed a mass in the terminal ileum and severe intraabdominal mucinous fluid. Intraabdominal gelatinous fluid protruding from the port site defect and a mass in the distal appendix were observed during operation. $\mathrm{He}$ underwent a right hemicolectomy, ileocolic anastomosis and peritoneal debridement; cytoreductive surgery was administered two months later due to mucinous tumor of the appendix. There are only a few case reports describing PMP presenting with an incisional hernia after open surgical procedures. To the best of our knowledge, this report describes the first case of PMP presenting with a port site hernia after a laparoscopic intervention.

Keywords: Appendix; cytoreductive surgery; HIPEC; port site hernia; pseudomyxoma peritonei

ÖZET

Pseudomyxoma peritonei (PMP), milyonda iki insidansı olan nadir bir hastalıktır. Akut apandisit, over kitleleri ve abdominal distansiyon en sık görülen prezentasyonlardır. Laparoskopik kolesistektomi öyküsü olan 72 yaşında erkek hasta, karın ağrısı ve supraumbilikal port giriş yerinde şişlik artışı ile başvurdu. Radyolojik incelemede terminal ileumda kitle ve karın içi şiddetli müsinöz sıvı görüldü. Operasyon sırasında port giriş yeri defektinden protrüde olan jelatinimsi sıvı ve distal apendikste kitle izlendi. Sağ hemikolektomi, ileokolik anastomoz ve peritoneal debridman yapıldı; Apendiksin müsinöz tümörü nedeniyle iki ay sonra sitoredüktif cerrahi uygulandı. Literatürde, açık cerrahi prosedürlerden sonra insizyonel herni ile ortaya çıkan PMP'yi tanımlayan sadece birkaç vaka vardır. Bildiğimiz kadarıyla bu çalışma, port hernisi ile başvuran ilk PMP vakasını tanımlamaktadır.

Anahtar kelimeler: Apendiks; sitoredüktif cerrahi; HIPEK; port hernisi; psödomiksoma peritonei. 


\section{INTRODUCTION}

Pseudomyxoma peritonei (PMP) is a rare disease characterized by accumulation of mucinous fluid in the peritoneal cavity. Incidence is thought to be two per million (1). It mostly originates from appendicular mucocele or mucinous ovarian tumor. $\mathrm{Mu}$ cinous cystadenoma starts with transformation of the goblet cells of the appendix vermiformis and continues with accumulation of mucinous fluid. Increasing pressure may cause perforation of the appendix and subsequent dissemination of the fluid in the peritoneal cavity. Acute appendicitis, ovarian mass, and abdominal distension are the most common presentations of PMP. New onset hernia is the first presentation in $14 \%$ of the patients (2). Cases of PMP presenting with predominantly inguinal, and umbilical, but rarely incisional hernia have been reported in the literature (1, $3)$. Herein, we aimed to present the diagnosis and treatment process of a patient presented with laparoscopic port site hernia and diagnosed with PMP secondary to mucinous tumor of the appendix. To the best of our knowledge, PMP presenting with a port site hernia has not been described before.

\section{CASE}

A 72-year-old male patient was admitted to the outpatient clinic with complaints of colicky abdominal pain and increased periumbilical swelling for two months. His medical history included type 2 diabetes mellitus, hypertension and also a laparoscopic cholecystectomy performed 10 years ago. Physical examination revealed abdominal distention, periumbilical protrusion and abdominal tenderness in the

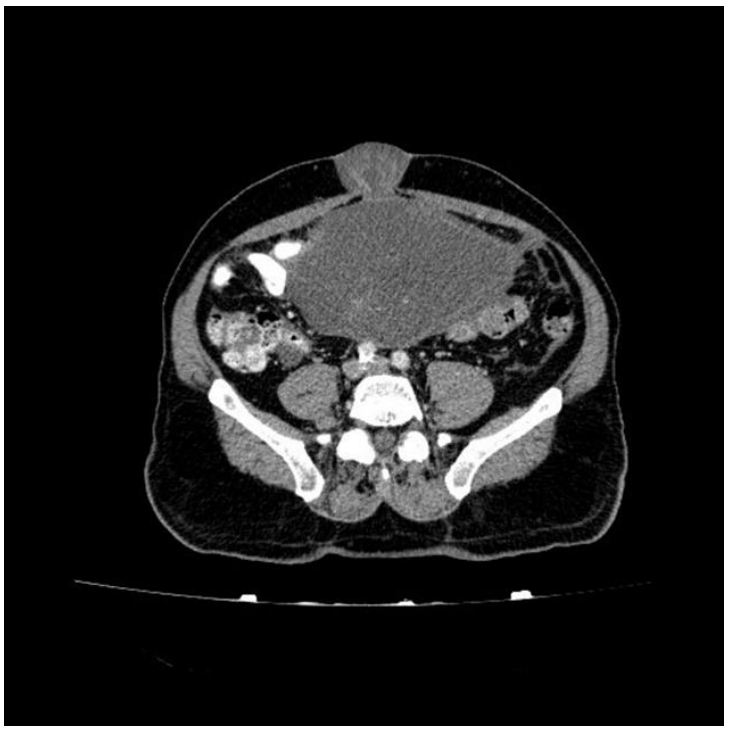

right lower quadrant. Laboratory parameters were within normal limits. Port site hernia was thought as an initial diagnosis, because file of previous operation revealed that supraumbilical $10 \mathrm{~mm}$ port defect was not sutured at the end of previous operation. Hernia was irreducible. Superficial soft tissue ultrasound revealed a $1.3 \mathrm{~cm}$ facial defect with gelatinous content near umbilicus. Computed tomography (CT) showed a multiloculated cystic mass located in the terminal ileum with a size of $19 \times 13 \times 16 \mathrm{~cm}$, and generalized intraabdominal fluid which herniated to the subcutaneous tissue at the supraumbilical port site (Figure 1). Laparotomy was planned with a prediagnosis of intraabdominal mass, possibly PMP (Figure 2a). In the intraoperative examination, it was observed that there was generalized intraabdominal gelatinous fluid which protruding from the port site defect (Figure $2 b$ ) and a mass of $6 \times 5 \times 4 \mathrm{~cm}$ was detected in the distal part of the appendix (Figure 2c). Frozen section analysis of the fluid sample was reported as mucinous fluid suggesting PMP. A right hemicolectomy, ileocolic anastomosis and peritoneal debridement were performed (Figure 2d). The patient was discharged uneventfully on the sixth postoperative day. Pathological examination confirmed low-grade mucinous tumor of the appendix and PMP. The patient was referred to another hospital and he underwent complete CRS and hyperthermic intraperitoneal chemotherapy (HIPEC) two months after the first operation and had remained well during 3-year follow-up period. Written informed consent was obtained from the patient who participated in this study.

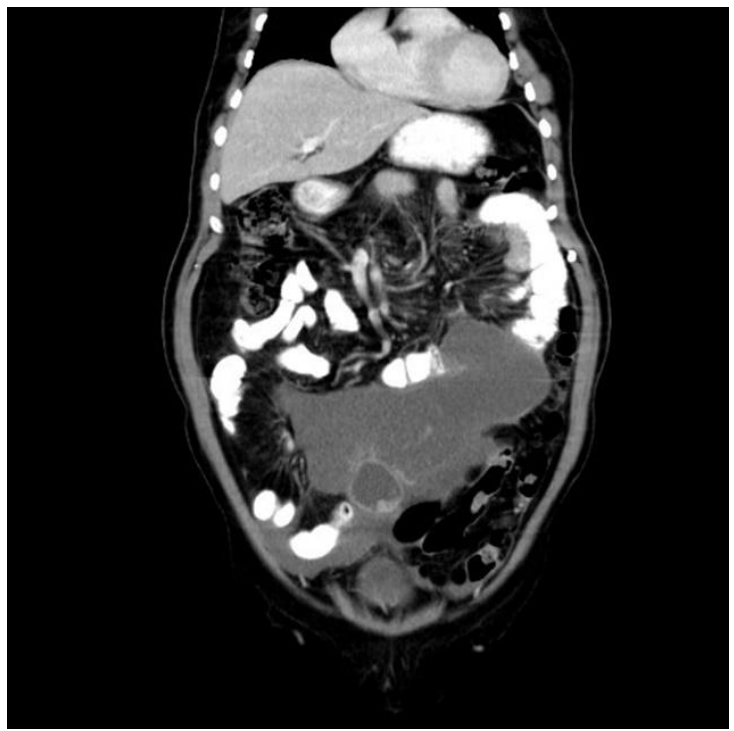

Figure 1: Axial (left) and coronal (right) sections of computed tomography revealing intraabdominal mucinous fluid. In Figure 1a, note that fluid is protruding through fascial defect. 

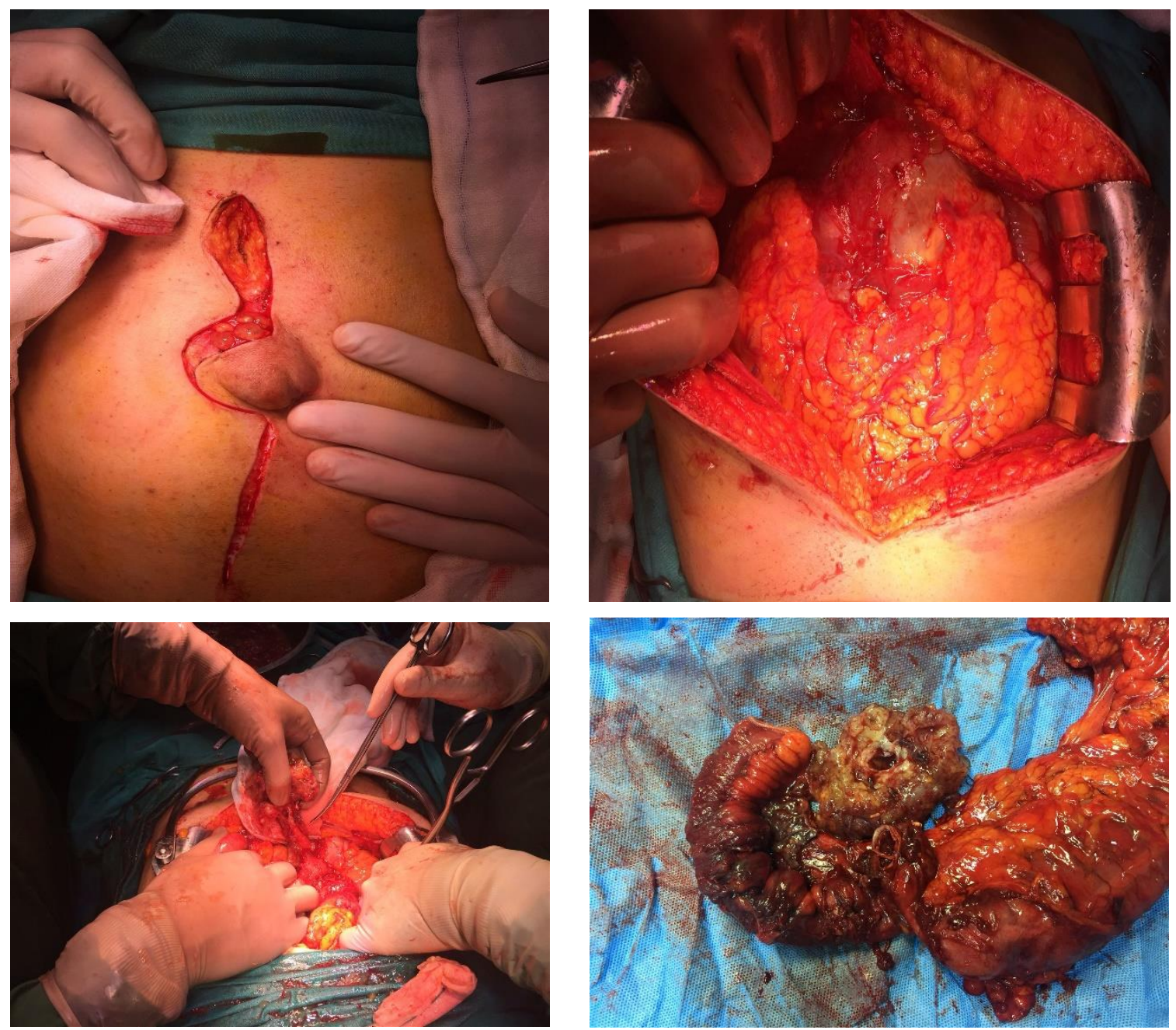

Figure 2: First row, Left: Laparatomy incision and protruding navel. Right: Intraoperative examination. Generalized intraabdominal gelatinous fluid is seen. Second row, Left: A 6x5x4 cm yellowish gelatinous tumor in the distal part of appendix. Right: Macroscopic view of resected specimen (after appendix was discreted).

\section{DISCUSSION}

PMP causes accumulation of mucinous fluid in high quantity in the peritoneal cavity. Increased abdominal pressure secondary to accumulation of the mucinous fluid is thought to force the previous incision or abdominal fascial defects and cause herniation of the mucinous fluid or intraabdominal organs (3). In the presented patient, laparoscopic port site had not be closed during laparoscopic cholecystectomy and 10 years later high intraabdominal pressure resulted in mucinous fluid to pass through fascial defect and accumulate in subcutaneous tissue. Consequently, patient was admitted to the hospital with a complaint of periumbilical swelling.

Diagnosis of PMP is challenging due to its rarity and occurring with different clinical presentations. Common symptoms such as abdominal pain, abdominal distension, and new onset hernia may be mostly evaluated as results of more familiar and more common diseases. Radiological screening can draw attention to suspicion of PMP.

CT was reported to be the most important diagnostic tool. Approximately 50\% of the patients were diagnosed by the help of CT abnormalities, especially in patients with suspicious symptoms or abdominal distension. On the other hand, one out of five patients were diagnosed during urgent surgery performed due to acute abdomen or on postoperative histopathological examination, while $5 \%$ of patients were diagnosed during investigation of a new onset hernia (4). Percutaneous biopsy is mostly nondiagnostic, because biopsy specimen consists of only acellular mucin. Presence of acellular mucin in biopsy specimen may be associated with PMP (1).

CRS and HIPEC are accepted to be gold standard treatment option and have improved the overall and disease-free survival of PMP patients significantly (1). In a multicentre study by Chua et al. (5), the overall 5-year, 10-year and 15-year survival rates of the patients underwent CRS and HIPEC were reported to be $74 \%, 63 \%$ and $59 \%$, respectively. This procedure involves high mortality and morbidity rates with a post-operative mortality rate reaching up to $2 \%$ and major complication rate reaching up to $24 \%$.

Neoadjuvant chemotherapy is not recommended due to absence of impact on survival. 
However, adjuvant chemotherapy was found to be beneficial in patients with high-grade neoplasms (1). The presented patient underwent CRS and HIPEC in a referral center. He was not administered adjuvant chemotherapy due to low-grade mucinous tumor.

Cases of PMP presenting with new onset hernia have been rarely reported. In the cases of irreducible port site hernia, the possibility of PMP should be kept in mind in cases with gelatinous fluid inside the hernia sac on ultrasound, and concomitant abdominal distention. Abdominal radiological screening should be performed preoperatively to avoid a surprising intraoperative diagnosis.

\section{REFERENCES}

1. Mittal R, Chandramohan A, Moran B. Pseudomyxoma peritonei: natural history and treatment. Int J Hyperth 2017;33:511-519.

2. Esquivel J, Sugarbaker H. Clinical presentation of the pseudomyxoma peritonei syndrome. Br J Surg 2000;87:1414-1418.

3. Ergul Z, Olcucuoglu E, Kulacoglu H, Dener C. Recurrent Incisional Hernia due to Pseudomyxoma Peritonei. Case Rep Med 2011;2011:853906.

4. Glaysher M, Gordon-Dixon A, Chandrakumaran K, Cecil TD, Moran BJ. Pseudomyxoma peritonei of appendiceal origin: mode of presentation in the modern era. Colorectal Dis 2014;16:53.

5. Chua TC, Moran BJ, Sugarbaker PH, Levine EA, Glehen O, Gilly FN, et al. Early- and longterm outcome data of patients with pseudomyxoma peritonei from appendiceal origin treated by a strategy of cytoreductive surgery and hyperthermic intraperitoneal chemotherapy. J Clin Oncol 2012;30:2449-2456. 